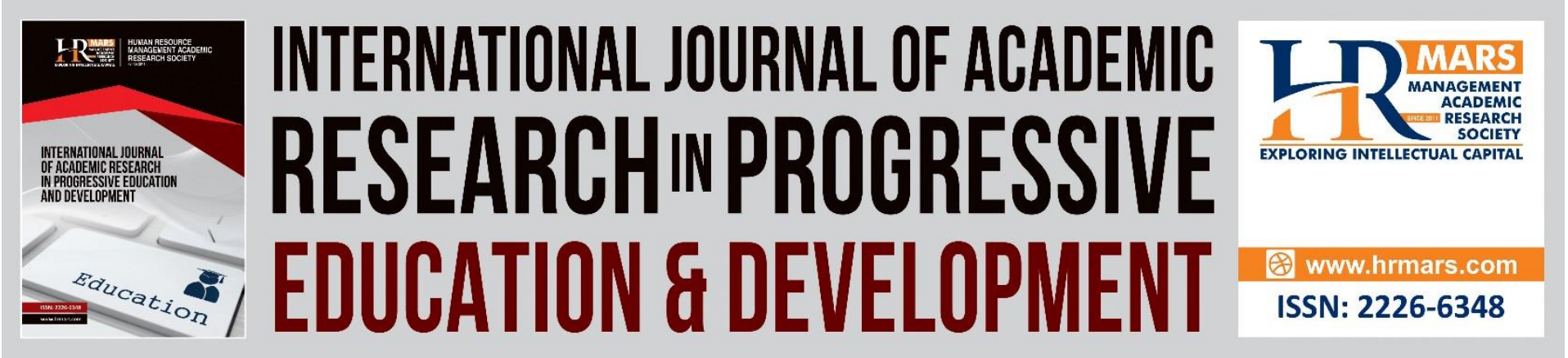

\title{
The Effectiveness of Brain-based Learning in Increasing Communication Skills Among Form 4 Students in Learning Malay Languages
}

\section{Rose Niza Salleh}

To Link this Article: http://dx.doi.org/10.6007/IJARPED/v10-i3/11479

DOI:10.6007/IJARPED/v10-i3/11479

Received: 09 July 2021, Revised: 29 July 2021, Accepted: 25 August 2021

Published Online: 22 September 2021

In-Text Citation: (Salleh, 2021)

To Cite this Article: Salleh, R. N. (2021). The Effectiveness of Brain-based Learning in Increasing Communication Skills Among Form 4 Students in Learning Malay Languages. International Journal of Academic Research in Progressive Education and Development, 10(3), 1062-1076.

Copyright: (c) 2021 The Author(s)

Published by Human Resource Management Academic Research Society (www.hrmars.com)

This article is published under the Creative Commons Attribution (CC BY 4.0) license. Anyone may reproduce, distribute, translate and create derivative works of this article (for both commercial and non-commercial purposes), subject to full attribution to the original publication and authors. The full terms of this license may be seen at: http://creativecommons.org/licences/by/4.0/legalcode

Vol. 10(3) 2021, Pg. 1062 - 1076

Full Terms \& Conditions of access and use can be found at http://hrmars.com/index.php/pages/detail/publication-ethics 


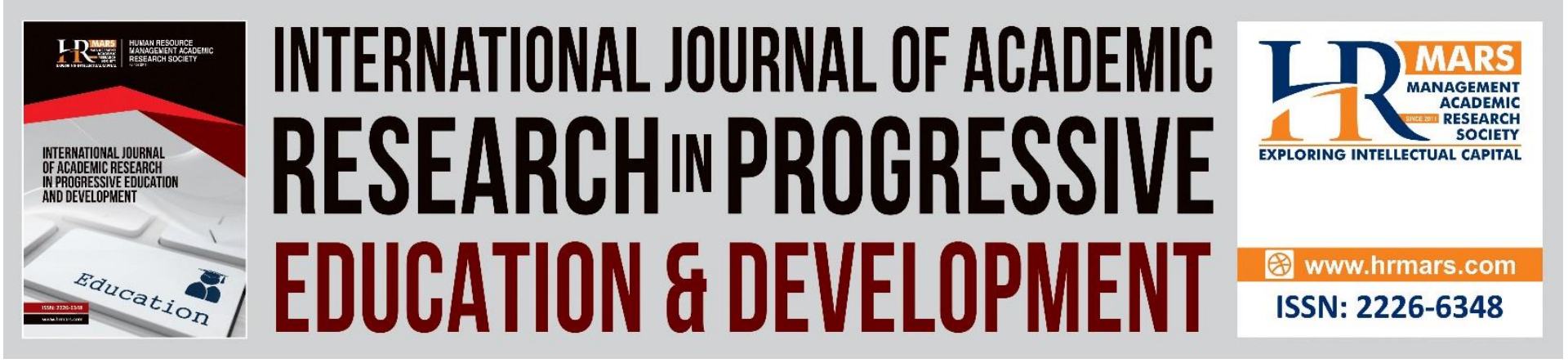

\title{
The Effectiveness of Brain-based Learning in Increasing Communication Skills Among Form 4 Students in Learning Malay Languages
}

\author{
Rose Niza Salleh \\ Universiti Pendidikan Sultan Idris, Tanjung Malim, Perak
}

\begin{abstract}
Communication skills is one of the most important elements in the 21st century learning. Teacher ability to teach language skills through active conversations among students is a basic skill in communication ability. This research explores the effectiveness of brain-based learning approach towards communication skills among secondary school students. The objectives is to identify the effectiveness of brain-based learning strategy to enhance Form 4 students' communication skills in the Malay Language subjects. This quasi-experiments research consists 60 Form Four students in two class of a secondary school in Manjung, Malaysia. Data is collected using the instrument of Students' Communication Skills Questionaire. This is a quantitative research and its data is analyzed in descriptive and inferensi using IndependentSamples t-test. During the teaching implementation of eight weeks, data related to communication skills has been collected. The research findings show that teaching with the brain-based learning approach has succeeded in increasing the communication skills with highly frequent justifications among the students during the learning of the Malay Language. Keywords: Brain Based Learning, Communication Skills
\end{abstract}

\section{Introduction}

Communication is one of the five elements in $21^{\text {st }}$ century learning which must be mastered by students apart from collaboration, critical thinking, creativity, and values in the context of teaching and learning Malay Language in Malaysia. The mastery of $21^{\text {st }}$ century learning is the center of increasing teaching qualities for it to be parallel to the current education development (Sulaiman \& Ismail, 2020). The implementation of communication skills among students is also important as it is one of the elements in $21^{\text {st }}$ century learning which is aligned with the goal of Kurikulum Standard Sekolah Menengah (KSSM) Bahasa Melayu which is to equip students with language ability and able to communicate to fulfill one's needs (KPM, 2018). It is based on the objective of Bahasa Melayu KSSM that teachers must use suitable approaches in applying communication skills among students.

The ability to teach language skills through active conversations among students is a basic skill in communication (Hussain, 2017) and may be activated through mastery of meaningful and effective communication skills among teachers and students (Yasin et al., 2020). The significance of connections between the teacher's teaching quality (Othman, 2017), attitude (Sintian et al., 2020), and the student's interests (Osman, 2013), is considered vital in forming 
the student's communication skills in teaching a language as it is said that the connection between the teacher's and the student's communication is the main success component in achieving the specified objectives and goal in a learning session (Han, 2017).

Numerous researchers have conducted researches regarding the suitable teaching approaches in applying and improving communication skills in learning languages; it is also stated to be connected directly with the student's speaking and conversing abilities. The research which applies brain-based learning is among the few effective approaches in improving conversing skills among students, (Febyan, 2017) and speaking skills (Khalil, 2019). The research by Hendriana et. al (2018), also found that students who applied brain-based learning succeeded in improving their communication skills and self-confidence. According to Jensen (2008), the technique and speaking strategy applied through brain-based learning can increase a student's interest in learning and helps the student to communicate. This is because the technique used in brain-based learning enables the students to be active in the classroom, develops their ideas, and at the same time creates opportunities for them to conduct group activities. All these activities will create opportunities for students to communicate actively and store information in their long-term memory.

Brain-based learning is a teaching and learning approach which is related to neuroscience. It is a basic knowledge based on a research of the brain integrated with learning practices in the classroom which combines mind, brain, and education (Sousa, 2017). Neuroscience and education have found a point whereby what is learnt about the human brain, its effects towards the teacher's daily actions, and its effects towards how the students think are somewhat related. Brain-based learning is a teaching and learning method which is designed to be aligned with the brain's characteristics and how it functions and learns.

Brain-based learning is an approach developed, created, and further enhanced by Caine \& Caine (1991); Jensen (1996); Sousa $(1995,2017)$. It is designed to create meaningful learning between the teacher and student involved. A student's ability to think and convey his or her thoughts is influenced by how the brain functions and thinks as a student who definitely possesses various level of intelligence compared to his or her peers. Therefore, to stimulate the brain to function optimumly in learning, a teacher has to create fun learning environments and challenge the students' thinking skills in increasing their engagement towards meaningful learning (Jensen, 2008).

\section{Background of Research}

Teaching and learning the Malay Language formally in the education system, communication skills are present when the teachers and students communicate to form reletionships, convey information, state opinions, express feelings and creative or critical ideas with the correct intonation and pronunciation; apart from conversing with grammatical sentences, (Dokumen Standard Kurikulum dan Pentaksiran, 2018). Formal communication normally takes place in a more polite and ethical manner. Communication may even take place verbally or non-verbally (KIT PAK21, 2017). Active communication in a learning session must indeed be the main focus of the teacher and effective learning of the students as a $21^{\text {st }}$ century classroom's learning practice. The MOE has stated that communication skills are the basic skills which must be mastered by the students. According to Caine \& Caine (1991, pg. 6) for brain-based learning, the active communication between teachers and students especially when the students are expressing their opinions or sharing information of the activity they are implementing - is 
further activated with the teachers' actions in giving new or old information - and makes the teaching and learning session more active.

In the effort of encouraging students to communicate, teachers must strive to create a safe and calm environment; Leslie (2014) suggested that it must be built based on trust and respect in a positive learning environment. The brain releases endorphine (a hormone which controls happiness and passion) which functions to stimulate the frontal lobe of the brain the centre of thinking commands (Sousa, 2017). Based on that, the strategy applied by brainbased learning is considered effective in applying communication skills in students. Readiness which is the first core aspect in brain-based learning (Caine \& Caine, 1991) requires teachers to create a safe and less risky teaching and learning environment.

\section{Problem Statement}

Feeling ashamed and scared (Febyan, 2017) and lack of self-confidence (Asmawati, 2008) are obstructions in the mastery of communication skills among students. This issue is the source of failure and limitations among students in stating their ideas and opinions which indirectly affects their academic achievements; as there is a significant relationship between the mastery of communication skills and academic achievements (Dazali, 2014). This problem does not end during secondary school. In fact, the issue of not mastering communication skills continue to institutes of higher education. Rashidi (2018) finds that communication skills of varsity students are still at a medium level. Research findings show that in these institutes, students not only face difficulties in communicating in the English Language; but they also face difficulties in communicating in the Malay Language which has been their language of instruction for 11 years during their school years. Rahman (2010), finds that the main reason of failure for one in his or her job is due to their failure in creating positive interactions with their surroundings. This is firmly based on the fact that one's communication abilities may increase their self-worth and assist them in their nature of work (Ibrahim \& Mahbob, 2021). The teaching approaches used by teachers do affect the students' $21^{\text {st }}$ century skills including communication skills (Ahmad et al., 2019). According to Brown 2002, in Khalil (2019), it is found that activities conducted by teachers which are focused on limited language structures as drilling activities are only able to benefit the students' short-term memory and are not able to increase their communication skills; in contrast to group activities which calms the students' emotions more. Apart from that, the brain functions better with activities that involve movements (Caine \& Caine, 1991) such as brainstorming (Khalil, 2019).

The one-way teaching method by teachers triggers many unwanted effects in the classroom thus causing boredom during the teaching and learning session. In contrary, when students are able to communicate effectively, this makes it easier for them as individuals or in a group to perform their roles and responsibilities as an organisation or a community. Effective communication skills require determination, experience, and passion towards the profession or nature of work that the students will be part of later in life. It also enhances positive values in further sharpening the students' emotional and social skills. The findings of the teachers' weaknesses in applying the $21^{\text {st }}$ century learning elements in teaching and learning is also reported in the findings from Jemaah Nazir Jaminan Kualiti (JNJK) Kementerian Pendidikan Malaysia in 2017 which monitored secondary schools in Manjung, Perak. It is found that the quality of the teachers' teaching and learning in several schools in Manjung is yet to shine in the aspects of applying $21^{\text {st }}$ century skills elements including the communication element in teaching which is evaluated among teachers and students in classrooms. 
DEVELOPMENT

Vol. 10, No. 3, 2021, E-ISSN: 2226-6348 @ 2021 HRMARS

\section{Research Objectives}

1. To determine the effectiveness of brain-based learning in Form 4 students' communication skills in the Malay Language.

2. To assist the teacher in assessing the Form 4 students' mastery level of communication skills in the Malay Language.

\section{Research Statement}

1. How effective is brain-based learning approach in enhancing the students' communication skills?

2. How may a teacher assess the Form 4 students' mastery level of communication skills in the Malay Language?

\section{Null Hypothesis}

1. There was no significant difference in terms of post-test scores of students' communication skills exposed to brain-based learning with students receiving conventional learning.

\section{Literature Review}

\section{Communication}

Students' ability to communicate actively and their attitude towards a language (Sintian et al., 2020 ) indirectly affects their mastery of the language. In schools, this communication skill is required to solve problems and complete tasks in the classroom. For long-term benefits, communication skills are required as a vital skill in facing life and at the workplace. In teaching and learning a language, this skill starts off with listening, speaking, reading, writing, grammar, and also language arts (KPM, 2018). Teachers and students who are able to master language skills communicate better. In the research by Tan (2017), a teacher's communications skills are vital in activating the students' communication skills and forming good positive relationships in the teaching and learning environment as it makes delivering information much easier (Hussain M. et al., 2017).

In the context of the $21^{\text {st }}$ century teaching and learning, KPM (2017) has listed out the communication skills that must be mastered by students in a teaching and learning session. The required communication skills are for the students to be able to observe, listen, and respond to others; to align their thinkings logically and stating them clearly and concisely; to understand how to adapt certain messages or methods and deliver them; and to be confident in interacting with their friends in any topic. Based on the literature review, there are several strategies suggested and has found to be effective in enhancing the students' communication skills such as questioning and answering (Mohd, 2020), independent discussions, task-based instructions, jigsaw puzzle, games, problem solving, drama, role-play, group activities, pairwork and oral reading (Khalil, 2019). Inter-class debate activity among students is also effective in enhancing the students's communication skills, (Nurakhir et al., 2020) in teaching a language.

\section{Brain-based Learning}

Brain-based learning is a teaching approach based on the strategy of benefiting the brain's functions in creating meaningful learning (Caine \& Caine, 1991). This knowledge was spearheaded by researchers such as Caine \& Caine (1991); Jensen (1996, 2004); Sousa (2001, 
2017) who researches about neuroscience and its benefits related to education. The brainbased learning approach is further explored in solving issues related to numerous fields. In the context of $21^{\text {st }}$ century learning, according to Sousa, (2017 pg. 1\&4), the teacher's understanding of how a brain functions in learning enhances the teaching and learning qualities. Teachers who use brain-based learning have been proven effective in enhancing their students' academic achievements (Akman et al., 2020). According to education and neuroscience researches, it is said that during learning, brain cells (neurons) become active while receiving stimulation from the sense organs; thus forming relations with one another (neural connections) to store information received from the learning activity. When many connections are formed, they will form neural networks. Firm neural networks depend on 3 factors : (i) the student's state of emotions; (ii) the student's learning experience; (iii) how meaningful and useful the learning is to the student (Sousa, 2017); the more and the stronger the neural networks built, the more it will be received and stored in long-term memory which is Hippocampus.

Brain-based learning is designed to assist teachers in understanding and mastering how the human brain works. Based on this understanding, teachers are able to use suitable strategies to enhance the students' learning. Teachers must realize the role that they play which vastly affects the students' brain Sousa (2017, pg. 5). According to Jensen, (2004), brain-based learning activities such as problem solving, collaboration, self discovery, physical movements, more questioning rather than answering, and stimulating the students' senses and mind are the best ways to generate the brain to act. These strategies are able to encourage the nerves to connect, increase brain mass, and enables memory to be stored in long-term. The brainbased learning strategies used are able to enhance the mastery of $21^{\text {st }}$ century skills among students.

The brain-based learning approach believes that various knowledge fields are related and that they share the same information and may be identified and arranged by the brain (Caine \& Caine, 1991 and Jensen, (2000.) It is also a strategy specifically designed to appreciate more and provide a thorough consideration towards the students' brain capability in a learning process. All researchers such as Caine \& Caine, 1991, pg. 126-159 and Saleh, (2018) pg. 25, think that there are 3 elements in brain-based learning which are as follows:

1. Relaxed Alertness - Teachers must create a calm and safe environment for students to be ready to share their knowledge, accept the knowledge being learnt, and be open to learn something new.

2. Orchestrated Immersion in Complex Experience- Teachers must prepare the students to learn through learning experiences which require them to give opinions and ideas and be actively involved throughout the whole learning session.

3. Active processing of experience- Students are given opportunities to relate between what is known to what is being learnt to generate knowledge through classroom activities done actively.

As there is a need to form connections between brain nerves and it involves complex interactions, therefore stimulations and interactions between these critical factors are needed to enhance the brain's function skills and also influence the students's learning process. Jensen (2014 pg. 34), has listed out seven critical factors in the learning process which are Engage, Repitition, Input Quantity, Coherence, Timing, Error Correction, and Emotion 
States. All these critical factors need to be interlocked and emphasized by teachers in their application of brain-based learning approach.

In building connections between education and the human brain, brain-based learning researchers have identified and stated principles which complete the brain-based learning approach. For instance, Caine dan Caine (1991 pg. 79), have listed out 12 principles as the base of brain-based learning general theory.

1. The brain implements processes in a parallel manner.

2. Learning involves the entire physiology function of humans.

3. The search for meanings is a natural process.

4. The search for meanings happens in patterns. (The brain always seeks for a pattern to search for meanings)

5. Emotions are critical patterns that influence learning.

6. The brain process happens partially and with others.

7. Learning involves focus, concentration, and perception.

8. Learning involves conscious and subconscious processes.

9. There are at least 2 types of memory: a system for memory and a system for memorization.

10. We remember and understand better if the facts and skills are applied naturally in our memory.

11. Learning becomes active by challenges and obstructed by threats.

12. Each brain is unique.

Based on the principle of brain-based learning, researchers such as Jensen $(1996,2004)$, Sousa $(2001,2017)$ Owen (2014) and Virginia (2017), unanimously state that, the students' existing knowledge related to the topic must be presented and it must be related to the new knowledge being taught in the process of creating a meaningful connection. Each core and the principle of brain-based learning are interrelated, and each principle complements each other. The understanding of brain-based learning principle is beneficial to guide teachers in applying purposeful approaches to activate the students' brain functions in mastering the skill required. This is due to the fact that the brain is directly involved and has connections with each action conducted between teachers and students.

\section{Brain-based Learning and Communication Skills}

Teachers who desire to increase language mastery among students often obtain positive and effective research findings through applying brain-based learning. Khalil (2019), who tested this approach on secondary school students in Egypt found that the students are able to speak accurately, pragmatically, and fluently. Cooperative learning strategies (Think-pair-share and Team-Pair-Solo), brainstorming, discussions, graphic organizers (mind maps, semantic maps, role-plays, comedy elements, authentic materials (video, reading aloud articles from international newspapers) and movements are proven effective in enhancing the students' speaking and communication skills. English songs and music were also benefited to create a calm environment, reduce the fear, increase movement, and encourage speaking skills. Group activities succeeded in calming the students' emotions and indirectly enhance the students' communication skills (Sousa, 2017). 
DEVELOPMENT

Vol. 10, No. 3, 2021, E-ISSN: 2226-6348 @ 2021 HRMARS

Febryan (2017) conducted a research on the effectiveness of brain-based learning towards speaking skills of SMA students found that this approach was effective in enhancing the students' speaking ability. Apart from that, the research by Mailis et al (2019) finds that using brain-based learning through Autograph was effective in enhancing the students' communication skills with the suitable learning instruments, strategies, and learning media. The research by Kraus \& Scwoch (2017) found that music is able to enhance the students' language and communication skills as retention or repeating of words in song lyrics are stored in long-term memory and makes the students' long-term memory more active.

\title{
Methodology \\ Research Participants
}

This research was conducted in a secondary school in Manjung, Perak. Form four students aged 16 to 17 from two classes were selected in this research $(N=50)$. This student from various achievement levels, races, and also boys and girls from the same class. Two form four Malay Language teacher also involved in this research. One experimental group $(N=25)$ and one control group $(\mathrm{N}=25)$ involved in this quasi-experiment research. This quantitative research using the Students Communication Skills Questionnaire. The items in the instrument were applied and modified based on the KIT PAK21 Module released by the MOE in 2017 and Dokumen Standard Kurikulum dan Pentaksiran (DSKP) BM, 2018. In guiding teachers to use the brain-based learning approach, the daily lesson plans were built based on the Brain-Based Learning Approach (PPBO) by Saleh (2018). This lesson plan will be used with the research instrument to identified the effectiveness of brain-based learning. The pilot test is conducted to check and ensure that the lesson plan and the instrument built are suitable to be utilized. The Brain-Based Learning Approach (PPBO), involves 7 teaching stepas as follows:

\author{
Step one : Students' activation \\ Step two : Giving the whole description \\ Step three : Making connections and building meanings \\ Step four : Conducting learning activities \\ Step five :Application and integration of students' concept/demonstration of \\ understanding \\ Step six : : Assessing all understanding/ reflection/ closure \\ Step seven : Preview of new concepts
}

\section{Research Method}

After obtaining the approval letters from Educational Planning and Policy Research (EPRD), Perak State Education Department, Manjung District Education Office, and school administrators, the researcher randomly chose 50 students from the two class. The pre-test is done to identify the level of communication skills possessed by the experiments and controls group. In this test, the researcher used the instrument of Students' Communication Skills Questionnaire. For the experiments group a teacher was guided to teach using the PPBO lesson plan. But the controls group just used the conventional method as usual. The teaching and learning session of Malay Language was implemented for eight weeks covering four themes based on the KSSM Malay Language Form 4 textbook.

Eight weeks were given for the teacher to use the brain-based learning approach as stated. The lesson plans consisted of various activities and tasks such as creating poems, conducting 
interviews, creating advertisement posters to promote businesses, and creating infographics for campaigns to save the environment. Each teaching session was allocated 60 minutes. Each task required the students to collaborate, communicate and discuss critically and creatively in presenting their discussion findings, create products, and also identify each group's strengths and weaknesses through brainstorming sessions. Appreciation was given to students as motivation and encouragement. All student activities require students to communicate actively by applying the cores and principles of brain-based learning. Suitable music was used in the teaching sessions while the students conducted activities.

After the teaching session, teacher did the post-test to assessed the students' communication skills using the Students' Communication Skills Questionnaire. Experiment and controls group were once again involved in this test. This instrument was used to identify the effectiveness of the brain-based learning approach in enhancing communication skills after the teacher has taught using PPBO. The effectiveness of the brain-based learning approach in enhancing the students' communication skills was measured before and after using PPBO to determine the outcome. The research data was then analysed using Independent-Samples T Test. Data was then collected and analysed to assess the students' level of communication skills after using the brain-based learning approach in teaching the Malay Language.

\section{Research Findings}

Pre-test Findings

Based on pre-test data, exsperiment group and control group obtaine mean score almost equivalent. Data collected using the Communication Skill Questionnaire Instrument. Based on 1a table, mean score for experimental group was 2.840 meanwhile, mean score for control group was 2.960. based on Independent-Samples t-test, table $1 \mathrm{~b}$ shows, mean score difference was ( $t=.452, d f=48, p=.653$ dan $p$ > 0.050). As for the test result, mean score different for both group were not significant. This indicate that, students communication skills for both both groups are equivalent.

Table 1a Pre-test Score: Students' Collaborative Skills Questionnaire for experiment and control group

\begin{tabular}{lcccc}
\hline Group & Number & Mean Score & Std. Deviation & Std. Error Mean \\
\hline Experiments & 25 & 2.840 & .943 & .188 \\
\hline Controls & 25 & 2.960 & .934 & .186 \\
\hline
\end{tabular}


DEVELOPMENT

Vol. 10, No. 3, 2021, E-ISSN: 2226-6348 @ 2021 HRMARS

Table 1b Analyse Independent-Samples t-test Pre-test score Students Collaborative Skills Questionnaire for experiment and control group

Lavene Test

t-test

\begin{tabular}{|c|c|c|c|c|c|c|c|c|}
\hline \multirow[t]{2}{*}{$\mathrm{F}$} & \multirow[t]{2}{*}{ Sig. } & \multirow[t]{2}{*}{$\mathrm{t}$} & \multirow[t]{2}{*}{ df } & \multirow{2}{*}{$\begin{array}{l}\text { Sig. } \\
\text { (2-tailed) }\end{array}$} & \multirow{2}{*}{$\begin{array}{l}\text { Mean } S \\
\text { difference }\end{array}$} & \multirow{2}{*}{$\begin{array}{l}\text { Std. Error } \\
\text { e difference }\end{array}$} & \multicolumn{2}{|c|}{$\begin{array}{c}95 \% \text { Confidence } \\
\text { interveal of difference }\end{array}$} \\
\hline & & & & & & & lower & upper \\
\hline .83 & .775 & .452 & 48 & .653 & -.120 & .265 & -.653 & .413 \\
\hline
\end{tabular}

Findings after using the brain-based learning approach

After that experimental group went through eight week of teaching session using the PPBO approach, post-test were administered to both group. Data were collected using a Student Communication Skills Questionnaire Instrument. The lesson plans need students to do various activities and tasks such as creating poems, conducting interviews, creating advertisement posters to promote businesses, and creating infographics for campaigns to save the environment to activate students' communication skills. At the same time, control group studied the same topics but learn conventionally. The findings of the post test data showed that the mean score of the experimental group increase to 3.75 on the likert scale compared to 2.96 for the control group. The result of the Independent-Samples t-test ( $t=4.224, d f=48$, $p=.000, p<0.050$ ) indicated that the test result were significant. There were differences between the two group of experimental dan control students. The mean difference value of .800 indicate the student of the experimental group using the brain-based learning approach were more able to master better communication skills than the controls group who experience conventional teaching method (mean values of both group can be shown from the Group Statistics result in table $2 b$ below.

Table 2a Post-test Score: Students' Communication Skills Questionnaire for experiment and control group

\begin{tabular}{lccccc}
\hline Group & Number & Mean Score & Std. Deviation & Std. Error Mean \\
\hline Experiments & 25 & 3.75 & .522 & .104 \\
\hline Controls & 25 & 2.960 & .789 & .157 \\
\hline
\end{tabular}


Table $\mathbf{2 b}$ Analyse Independent-Samples t-test Post-test score Students communication Skills Questionnaire for experiment and control group

Lavene Test

\begin{tabular}{|c|c|c|c|c|c|c|c|c|}
\hline & Lave & ne Test & & & & t-test & & \\
\hline \multirow[t]{2}{*}{$\mathrm{F}$} & \multirow[t]{2}{*}{ Sig. } & \multirow[t]{2}{*}{$\mathrm{t}$} & \multirow[t]{2}{*}{$d f$} & \multirow{2}{*}{$\begin{array}{c}\text { Sig. } \\
\text { (2-tailed) }\end{array}$} & \multirow{2}{*}{$\begin{array}{l}\text { Mean } S \\
\text { difference }\end{array}$} & \multirow{2}{*}{$\begin{array}{l}\text { Std. Error } \\
\text { e difference }\end{array}$} & \multicolumn{2}{|c|}{$\begin{array}{l}\text { 95\% Confidence } \\
\text { interveal of difference }\end{array}$} \\
\hline & & & & & & & lower & upper \\
\hline .771 & .384 & 4.224 & 48 & .000 & .800 & .189 & .419 & 1.180 \\
\hline
\end{tabular}

This result shows that by using the PPBO method in teaching and learning the Malay Language, is significant to enhance their communication skills compared to convensional teaching method. Based on the table shown, it can be concluded that the 7 Steps of PPBO has given a positive impact towards enhancing the communication skills of students involved in this research. Therefore, the research findings has proven that null hypothesis was rejected. Its means the brain-based learning approach is effective in enhancing communication skills and the teacher has succeeded in identifying the students' communication skills.

\section{Discussion}

The research findings show that by using brain-based learning strategy applied by the teacher, has succeeded in enhancing the mastery level of the communication skills with very frequent justifications for each action related to communication skills in teaching the Malay Language. The experiments group which implements brain-based learning as opposed to conventional learning in controls group have shown different achievement in communication skills during post-test. The mean score for communication skills of experimental group students increased from 2.840 in pre-test to 3.75 in post-test while control group students did not show any improvement of their collaborative skills in pre-test and post-test by recording the mean score of 2.960. This suggests that brain-based learning approach effective to enhance communication skills among students in Malay Language subject. This clearly shows that PPBO has succeeded in enhancing the students' communication skills. This occurred due to the readiness, blended teaching techniques which were adequately planned, and the active process existing in the classroom which stimulated the students' confidence to communicate actively.

According to Caine dan Caine, 1991, each core of brain-based learning which consisted of Active Processing of Experience, Relaxed Alertness, and Orchestrated Immersion in Complex Experience complemented each other as they required the students to explain, describe, make connections, and do active processes. All these activities require active communications between the teacher and the students to achieve the objectives set. The teacher's wisdom in creating activities which combine all these cores gives a direct impact towards the students' communication skills.

In communication skills, research findings show that students have succeeded in mastering and frequently implementing all measured skills which were to give verbal responses with grammatical sentences, process information in a structured manner, interact confidently and grammatically, read with various reading techniques and produce suitable intonation, and also think logically for the purpose of explaining information. Apart from strengthening linguistic mastery, students were trained to speak actively and use grammatical sentences 
ethically. The teacher found out that the students succeeded in overcoming their shyness and low self-confidence in solving problems and tasks in the classroom. The communication between the teacher and the students became much better after conducting all the activities. Tasks designed which required the students to collaborate, communicate and discuss critically and creatively in presenting their discussion findings, create products, and also identify each group's strengths and weaknesses through brainstorming sessions created active learning environments. Meanwhile, the appreciation given to students by the teacher and their peers is beneficial as motivation and encouragement for the students to feel comfortable, calm, and safe (Mazlin \& Iksan, 2018) which will increase student motivation in brain-based learning classrooms. All student activities which apply the cores and principles of brain-based learning such as combining the students' existing knowledge and the new knowledge taught will enable communication to become active among students.

The active movement of students in language activities such as role-play and simulations creates a language experience which increases the students' confidence to communicate as the teacher provides sufficient space and opportunities for the students to prepare before presenting a task or acting out a real life situation. This meaningful learning produced through learning experiences of PPBO provides active activities which involves visual, audio, and kinesthetics (Saleh, 2011) and prepares the students to be involved in activities in a more fun, active, and proactive manner (Fadil dan Saleh, 2016). Research findings also show that during the students' activities of role-play and discussions, they were provided with ample opportunities to practise communicating with various styles of the Malay Language grammatically and with the correct vocabulary.

The use of various illustrations and infographics produced were aimed at simplifying the information conveyed by using technology and it also provided opportunities for the students to communicate creatively; apart from storing memories in their long-term memory and help in creating mind maps in the students' minds. The use of mind maps complemented with suitable music in this research was clearly effective in enhancing the students' communication skills in teaching a language. It conforms to the findings by Khalil, (2019), on the usage of various mind maps, listening to music, and reading short stories which were proven to enhance speaking skills and student communication in learning a language. This is due to the fact that music which is suitable and used in a teaching session while the students conduct an activity is important in making language learning active (Abdullah \& Hussin, 2018).

In this research it can be concluded that the brain-based learning approach is able to enhance the students' communication skills. This finding is also proven by the research of Febyan (2020) which found that the brain-based learning approach has succeeded in enhancing the students' conmmunication and speaking skills.

\section{Summary}

Based on this research, the PPBO is effective in enhancing the students' mastery of $21^{\text {st }}$ century skills in the Malay Language. The 7 steps PPBO of the teaching and learning process of bbl in the Malay Language specifically in assisting to fortify the teachers' teaching methods to implement, apply, and assess the students' $21^{\text {st }}$ century skills have succeeded in enhancing the mastery of $21^{\text {st }}$ century skills among students and the PPBP approach in generating $21^{\text {st }}$ century skills which was suitable to apply in the Malay Language. The research findings clearly show that the brain-based learning can be used to help teachers and students in understanding and maximizing the brain's function and usage in stimulating critical and 
creative thinking skills in order to prepare students with multiple social skills such as social skills and thinking skills apart from being able to combine all the $21^{\text {st }}$ century elements through a positive and consistent self value system as needed by citizens in the $21^{\text {st }}$ century.

\section{References}

Abdullah, M. A. R., \& Hussin, S. (2018). Penggunaan Lagu dalam Meningkatkan Penguasaan Kosa Kata dalam Kalangan Pelajar Bahasa Jepun di Universiti Putra Malaysia: Usage os Songs in Enhancing Vocabulary Acquisition among Japanese Language Learners in Universiti Putra Malaysia. The Sultan Alauddin Sulaiman Shah Journal (JSASS), 5(2), 279288.

Akman, M. S. (2020). World Trading System under Stress: Scenarios for the Future. Policy Insights. 11(3), 360-366.

Ab Hakim, N. A., \& Iksan, Z. (2018). Kesan Pendekatan Pengajaran Berasaskan Otak Terhadap Motivasi Pembelajaran Fizik. Seminar Antarabangsa Isu-Isu Pendidikan. 210-224

Asmawati, E., \& Ruth, J. J. (2008). Combining Individual Learning and Group Discussion in Calculus Course. In: Proceedingthe 3rd International Conference on Mathematics and Statistics: Mathematics and Statistics: Bridge for Academia, Business, And Government in The Entrepreneurial Era. Department of Statistics department Of Mathematics Institut Pertanian Bogor, Bogor, Pp. 847-851.

Ahmad, N. L., Sho, S. L., Wahid, H., \& Yusof, R. (2019). Kepentingan Amalan Pengajaran dan Pembelajaran Abad 21 Terhadap Pembangunan Pelajar. International Journal of Education, Psychology and Counseling, 4(28), 37-51.

Bonomo, V. (2017). Brain-based learning Theory. Journal of education and human development. 6(1), 27-43.

Caine, R. N., \& Caine, G. (1991). Teaching and the human brain. ASCD Publication.

Dazali, M. N. S., \& Awang, M. I. (2014). Tahap kemahiran komunikasi dalam kalangan pelajar Sarjana Muda Pendidikan IPTA di Utara Semenanjung Malaysia. Jurnal Pendidikan Bahasa Melayu; Malay Language Education (MyLEJ), 4 (2). pp. 44-56.

Fadel. (2014). $21^{\text {st }}$ century skills: learning for life in our time $1^{\text {st }}$ edition. Jossey-Bass.

Fazil, F., \& Saleh, S. (2016). Keberkesanan Pendekatan Pengajaran Berasaskan Otak Dalam Meningkatkan Kefahaman Pelajar Tingkatan Empat Terhadap Pembelajaran Konsep Dan Mekanisme Fotosintesis. Asia Pacific Journal of Educators and Education. 31. 6983.

Febyan, F., Dhilion, H. R. S., Ndraha, S., \& Tendean, M. (2017). Karakteristik Penderita Kolelitiasis Berdasarkan Faktor Risiko di Rumah Sakit Umum Daerah Koja. Jurnal Kedokteran Meditek, 23(63).

Han, F., Wang, Han, Z., Feifei. (2017). Metacognitive knowledge and metacognitive control of writing strategy between high and low-performing Chinese EFL writers. Theory and Practice in Language Studies, 7(7), 523-532. 10.17507/tpls.0707.04.

Hendriana, H., \& Maya, R. (2018). Enhancing the Mathematical Communication Ability and Self-confidence of Junior High School Students Using Brain-Based Learning. Mathematics Education Journal. 2, 75. 10.22219.

Hussain, M. D., Lateh, M., Halim, M. S. (2017). International Journal of Business and Technopreneurship, 7(1), 23-38

Ibrahim, N. A. N., \& Mahbob, M. H. (2021). Keterampilan Peribadi Pelajar Sebagai Satu Bentuk Kemahiran Komunikasi dan Kepentingannya dalam Pasaran Dunia Pekerjaan Universiti 
Kebangsaan Malaysia. Jurnal Komunikasi: Malaysian Journal of Communication. 37(1), 209-226.

Imanuel, W., \& Mariani, S. (2019). The Effectiveness of Brain Based Learning Assisted by Schoology towards Students Creative Thinking and Self-Efficacy. Journal of Primary Education. 8 (9), 274-281.

Jensen, E. (2008). A fresh look at brain-based education. SAGE Publication.

Jensen, E. (2008). Brain-based learning: A New Paradigm of Teaching (2 ${ }^{\text {nd }}$ ed.). Thousand Oak, CA: Corwin Press.

Leslie, O., \& Wilson. (2014) "Multiple Intelligence Indicators." The Second Principle.

Khalil, B., \& Lewis, T. (2019). Understanding language teacher autonomy: A critical realist perspective on EFL settings in Turkey. International Online Journal of Education and Teaching (IOJET), 6(4). 749-763

Kraus, N., \& Banai, K. (2017). Auditory-Processing Malleability: Focus on Language and Music Current Directions in Psychological Science, vol. 16, (2), 105-110.

Mailis, T., Zubainur, C. M., \& Bahrun, (2019). Students' Mathematical Communication Ability through the Brain-Based Learning Approach using Autograph. Journal of Research and Advances in Mathematics Education, 4 (1), 1-10.

Mazlin N. A., \& Iksan Z. (2018). KESAN PENDEKATAN PENGAJARAN BERASASKAN OTAK TERHADAP MOTIVASI PEMBELAJARAN FIZIK. Seminar Antarabangsa Isu-Isu Pendidikan (ISPEN2018). 210-224.

Mohd, N. A. M., Ariffin, K., Darus, N. A., \& Alias, A. (2020). The Perceptions of Students'

Experiential Learning in Relation to Theoretical Concept with Real Practice. International Journal of Academic Research in Progressive Education and Development, 9(4), 25-34.

Nurakhir, A., Yuliasri, I., \& Bharati, D. (2020). The Demonstration of Linguistic, Cognitive and Socio-cultural Dimensions of Academic Literacy in Nursing Students' Written Texts. JPI Jurnal Pendidikan Indonesia, 9, 413. 10.23887.

Osman, Z. (2013). Pembangunan modul pengajaran Bahasa Melayu secara bersepadu. PhD thesis. University of Malaya.

Othman, Y. (2017). Keberkesanan Petak Pemikiran dalam meningkatkan kemahiran menulis esei bahasa Melayu dalam kalangan pelajar tingkatan 6. Jurnal Pendidikan Bahasa Melayu: Malay Languange Education (MyLEJ), 4(1), 44-45.

Rashdi, A. (2018). Kompetensi Interpersonal Dalam Kalangan Pelajar Universiti Malaysia Pahang (UMP): Satu Analisis. International Journal of Humanities Technology and Civilazation. 1(4), 106-121.

Saleh, S. (2018). ABC Pendekatan Pengajaran Berasaskan Otak. Penerbit USM.

Sintian, \& Minah. (2021). Attitude of Students towards Cooperative Skills in Learning Kadazandusun Language in Malaysia. Turkish Journal of Computer and Mathematics Education (TURCOMAT). 12. 267-272.

Sousa. (2017). How The Brain Learns. Thousand Oak Corwin Press.

Sousa. (2006). How The Brain Learns. Hawker Brownlow Education.

Tan, C. (2017). Mindful Teaching: Shu (Putting Oneself in the Other's Place) and the Golden Rule (Do to Others as You Would Have Them Do to You), Mindful Education, (123-139).

Triana. (2019). Analytics for learning design: A layered framework and tools. British journals of educational technology. 50 (1), 139-152.

Utomo, D. H. (2021). The Effect of Problem Based Learning on Problem Solving and Scientific Writing Skills. International Journal of Instruction, 14(2),11-26. 
INTERNATIONAL JOURNAL OF ACADEMIC RESEARCH IN PROGRESSIVE EDUCATION AND

DEVELOPMENT

Vol. 10, No. 3, 2021, E-ISSN: 2226-6348 ㄷ 2021 HRMARS

Virginia, D. (2017). Brain-Based Learning Theory. Journal of Education and Human Development, 6 (2), 1-12.

Yahaya, A., \& Shaharim, S. A. (2016). Kesesuaian Persekitaran Pembelajaran, Interaksi GuruPelajar, Komitmen Belajar Dan Keselesaan Pembelajaran Dalam Kalangan Pelajar Biologi. Jurnal Pendidikan Sains \& Matematik Malaysia, 6, 101-120.

Sulaiman, J., \& Ismail, S. N. (2020). Teacher Competence and 21st Century Skills in Transformation Schools 2025 (TS25). Universal Journal of Educational Research, 8(8), $3536-3544$. 